\title{
Phase transformation and shape memory effect of a Cu-Al-Ni- Mn-Nb high temperature shape memory alloy
}

\author{
E. M. Mazzer ${ }^{1,2}$, C. S. Kiminami ${ }^{1}$, C. Bolfarini' ${ }^{1}$ R. D. Cava ${ }^{1}$, W.J.Botta ${ }^{1}$, P.Gargarella ${ }^{1}$, F. \\ Audebert $^{2,3,4}$, M. Galano ${ }^{2}$
}

${ }^{1}$ Department of Materials Engineering, Federal University of São Carlos, São Carlos, SP, Brazil

${ }^{2}$ Department of Materials, University of Oxford, Parks Road, OX1 3PH, Oxford, UK

3 INTECIN, Faculty of Engineering, University of Buenos Aires, Paseo Colon 850, (1063) Ciudad de Buenos Aires, Argentina

4 Department of Mechanical Engineering and Mathematical Sciences, Oxford Brookes University, Wheatley Campus, OX33 1HX, Oxford, UK

Corresponding author: eric.marchezinimazzer@materials.ox.ac.uk

\section{Abstract}

The microstructure, phase transformation and shape memory effect of the high temperature shape memory alloy $\mathrm{Cu}-11.4 \mathrm{Al}-3.2 \mathrm{Ni}-3 \mathrm{Mn}-0.5 \mathrm{Nb}$ (wt\%) were investigated for the first time. The shape recovery ratio can achieve $73 \%$ when submitted to $690 \mathrm{MPa}$ and the compressive stress of fracture of the alloy is $1560 \mathrm{MPa}$.

\section{Keywords}

- Copper alloys;

- Shape memory alloys (SMA);

- Phase transformation

\section{Introduction}

High temperature shape memory alloys (HTSMAs) have been attracting the attention of research groups due to their possible suitability for engineering applications in thermosensitive devices that operate above $100^{\circ} \mathrm{C}$ [1]. For this purpose, the phase transformation involving the shape memory effect must be above this temperature. The most widely used shape memory alloy (SMA) NiTi does not fit this requirement and can be only be used up to about $80^{\circ} \mathrm{C}$ [2]. Therefore, many attempts have been made on the Ni-Ti system to shift the martensitic transformation to higher temperatures 
by the addition of different elements, thus obtaining the ternary system Ni-Ti-X ( $\mathrm{X}=\mathrm{Zr}$, $\mathrm{Pd}, \mathrm{Hf}$ ) [3], [4], [5],[6], [7], [8] and [9]. However, these alloys' drawback is their high production challenges such as high reactivity of the elements with oxygen and furthermore the high production costs associated. Hence, the search for new systems with shape memory effect (SME) promoted the study of Cu-based SMA such as CuZn-Al, Cu-Al-Ni, Cu-Al-Nb, Cu-Al-Ta and Cu-AlFe [10], [11], [12], [13], [14], [15] and [16]. Despite the well-known brittleness of the polycrystalline Cu-Al-Ni SMA, it still attracts the attention of researchers because it is one system that fits all the requirements of a HTSMA. Many attempts to improve the mechanical properties of the $\mathrm{Cu}-\mathrm{Al}-\mathrm{Ni}$ alloys have been achieved by the addition of elements, such as $\mathrm{Mn}, \mathrm{B}, \mathrm{Ti}, \mathrm{V}, \mathrm{Zr}, \mathrm{Co},[17]$ but also by refinement of the microstructure by different thermomechanical processing routes [18], [19], [20], [21], [22] and [23]. Nonetheless there are still many application problems that require further work on these systems. To design a good HTSMA that can be used at high temperature without degrading its properties several aspects such as the mechanical properties, the thermal stability (usually around $100-200{ }^{\circ} \mathrm{C}$ for $\mathrm{Cu}$ based alloys) and an acceptable recoverable transformation strain level $(>0.5 \%$ ) [24] combined with a high recovery stress (>200 MPa) should be considered [1] and [17]. Therefore, this work investigates the shape memory effects and the phase transformation of a Cu-Al-Ni-Mn alloy with a small addition of $\mathrm{Nb}$ produced by spray-forming. Preliminary results on this HTSMA show an extraordinary behavior: the maximum recovery strain achieved was around $1 \%$ when subjected to $690 \mathrm{MPa}$, with a recovery ratio of $73 \%$.

\section{Materials and methods}

The $\mathrm{Cu}-11.35 \mathrm{Al}-3.2 \mathrm{Ni}-3 \mathrm{Mn}-0.5 \mathrm{Nb}$ (wt\%) alloy was prepared by spray-forming. Details of the process can be found at [19]. The composition measured by Inductively Coupled Plasma-Atomic Emission Spectrometry (ICP-OES) was Cu-11.29Al-3.10Ni-2.85Mn$0.35 \mathrm{Nb}$ (wt\%). The microstructure was analyzed by optical microscopy, scanning electron microscopy (SEM, Philips XL 30 FEG-SEM), X-ray diffraction with $\mathrm{Cu} \mathrm{Ka}$ radiation (XRD, Siemens D5005) and transmission electron microscope (TEM, JEOL $2000 \mathrm{FX}$, at $200 \mathrm{kV}$ ). Differential scanning calorimetry (DSC, NETZSCH 200 F3 calorimeter) was carried out at a rate of $40^{\circ} \mathrm{C} / \mathrm{min}$ in order to measure the temperatures of the martensitic/austenitic phase transformation. The compression tests were performed on a Testometric Micro $500-50 \mathrm{kN}$ with crosshead speed of $0.5 \mathrm{~mm} / \mathrm{min}$, using cylindrical specimens with $4 \mathrm{~mm}$ in diameter and 8 in length. The SME was evaluated with different pre-stress applied on the samples and analyzed based on the original sample length $\left(l_{0}\right)$, length after unloading $\left(l_{1}\right)$ and length after heat treatment $\left(I_{2}\right)$. The heat treatment was done above the final austenitic temperature $\left(A_{t}\right)$ 
at $280{ }^{\circ} \mathrm{C}$ for $10 \mathrm{~min}$. The residual strain after unloading $\left(\varepsilon_{r}\right)$ and the recovery strain ( $\left.\varepsilon_{\text {SME }}\right)$ were calculated as: $\varepsilon_{1}=\left(l_{0}-I_{1}\right) / l_{0} \times 100 \%$, and $\varepsilon_{\text {SME }}=\left(l_{2}-I_{1}\right) / l_{0} \times 100 \%$, respectively. The recovery ratio was calculated as: $\mathrm{R}=\left(\varepsilon_{\mathrm{SM}} / \varepsilon_{\mathrm{r}}\right)$.

\section{Results and discussion}

Fig. 1(a) shows the microstructure at room temperature of the as-deposited alloy. The microstructure is homogeneous and no heat treatments were performed after the processing of the alloy. The austenitic originated grain size and the porosity are $24.1 \pm 1.4 \mu \mathrm{m}$ and $0.5 \pm 0.3 \%$, calculated using a method showed in [25]. The grain size was refined around $82 \%$ when compared with others alloys with similar composition but without $\mathrm{Nb}$ content, and similar processing route, for which the grain size is around $135 \mu \mathrm{m}$ [26]. Twinned martensites laths can be observed inside the grains originated in the austenitic field. These laths correspond to different variants of martensites. TEM bright field image from the as-cast samples shows nanoscale twinned martensites can be seen in Fig. 1(b). The selected area electron diffraction (SAED) from this region along the [100] zones axis of the martensites is shown in Fig. 2(c). The diffracted spots show reflections from different martensites variants. Its indexation gives interplanar distances corresponding to the monoclinic $\beta^{\prime}$ phase. The convergent beam electron diffraction inFig.1(c) was taken from one variant and shows the reflections from the [100] zone axis and corroborates the previous SAED. Fig. 2 shows the XRD diffraction pattern of the alloy at room temperature. One predominant phase, the monoclinic $\beta^{\prime}$, was found, corroborating what was observed by TEM. The indexation of the cell parameters using the Rietveld method gave the lattice parameters shown in Table 2.
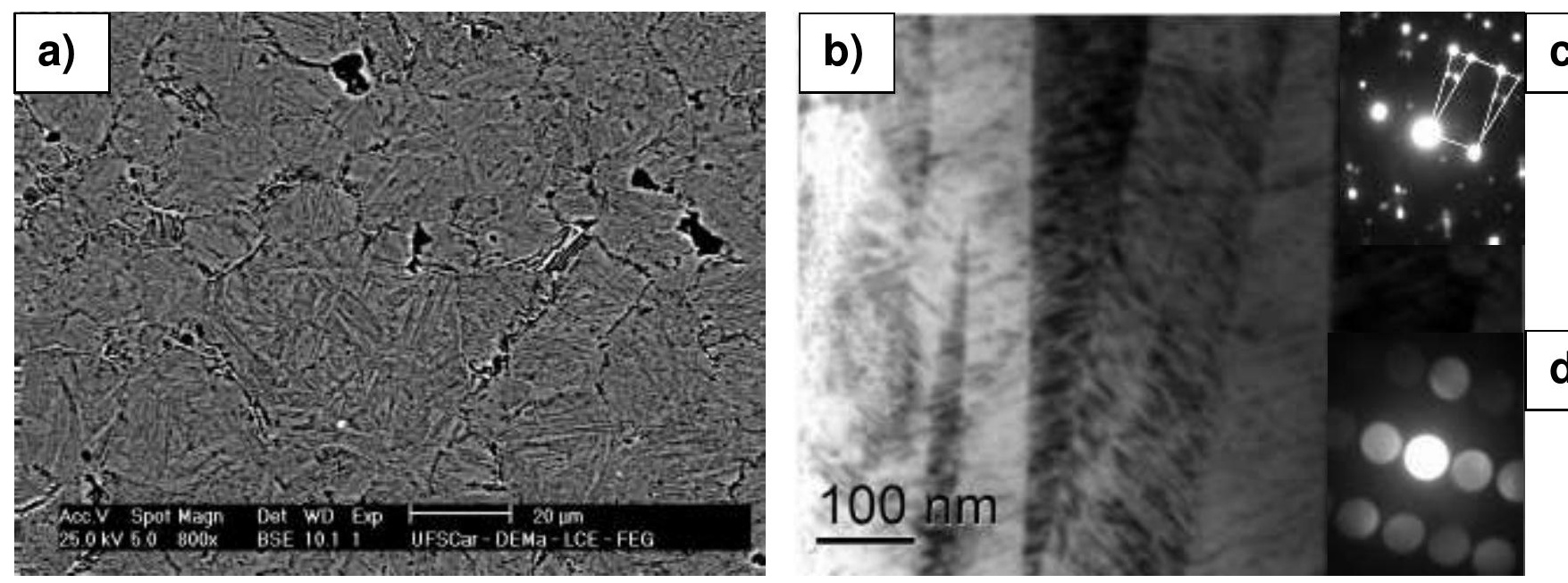

Fig 1: a) SEM micrograph of the as-deposited Cu-11.35Al-3.2Ni-3Mn-0.5Nb (wt\%). b) Bright field TEM image showing the martensite twinned laths, c) SAED near the [100] zone 
axes from several martensite variants and d) convergent beam diffraction from one of the martensite variants along [100] zone axes of the $\beta$ ' monoclinic martensite.

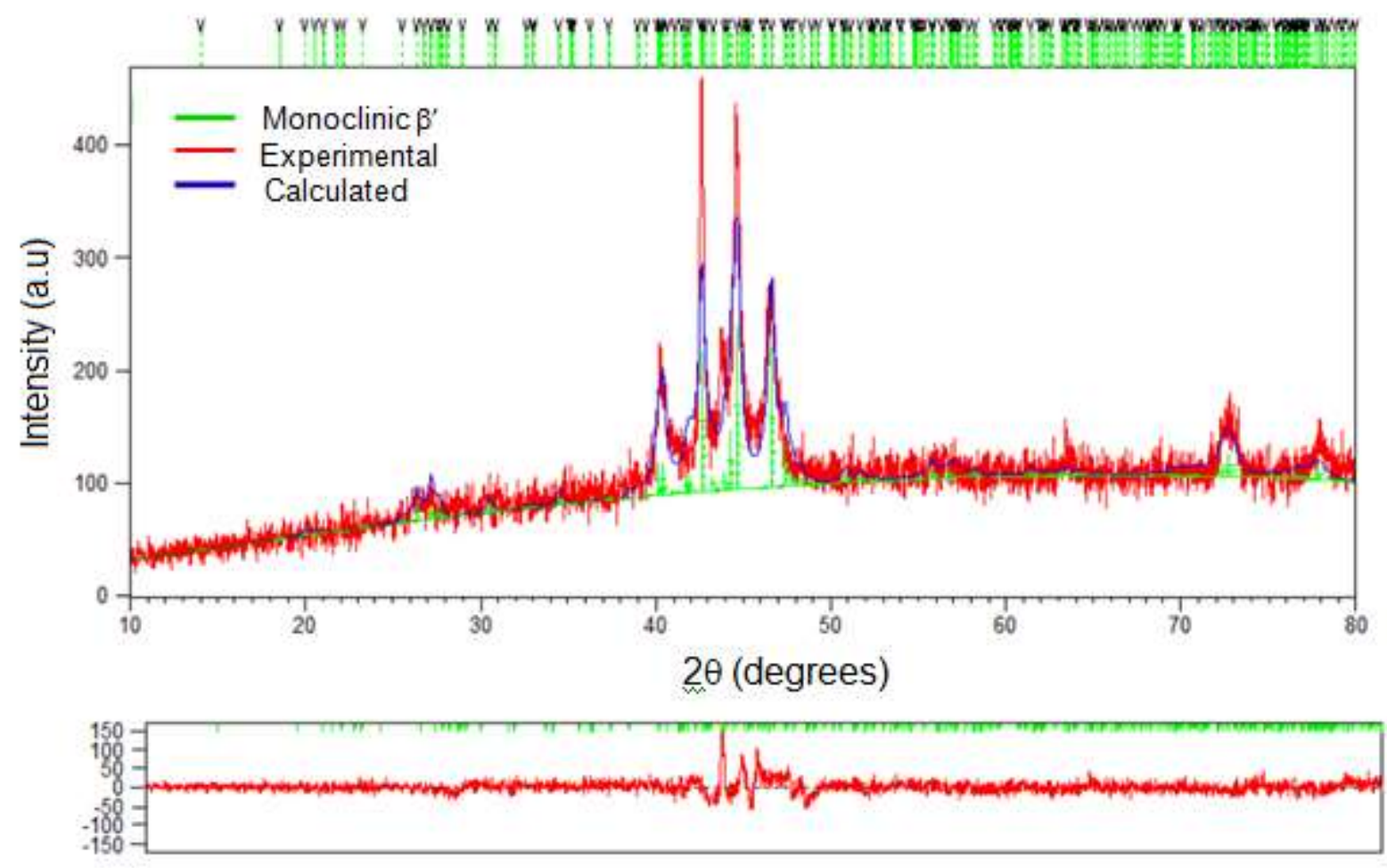

Fig 2: XRD pattern of the alloy and the plot of difference between the experimental and calculated patterns. Peaks from the monoclinic $\beta^{\prime}$ martensite (Space group P21/m) can be observed. The Rietveld analysis was carried out in a heat treated sample in order to release lattice strains from the processing of the alloy. Cell parameters of the monoclinic $\beta$ ': $a=0.4500$ $\mathrm{nm}, \mathrm{b}=0.5224, \mathrm{c}=1.2825, \beta=95.6^{\circ}$.

Fig. 3 shows the DSC curve for the Cu-11.35Al-3.2Ni-3Mn-0.5Nb (wt\%). An endothermic peak on the heating step characterizes the reverse transformation, whereas the forward transformation shows an exothermic on the cooling step. The transformation temperature was taken from the second DSC cycle in order to eliminate the influence of any quenched-in vacancies. Table 1 presents the transformation temperatures $A_{s}, A_{t}, M_{s}, A_{t}-A_{s}, A_{t}-M_{s}\left({ }^{\circ} \mathrm{C}\right)$ and the melting point $T_{m}$ for the as-deposited sample. It can be observed that the onset austenitic start $\left(A_{s}\right)$ and final $\left(A_{t}\right)$ transformation temperatures are $94^{\circ} \mathrm{C}$ and $195^{\circ} \mathrm{C}$, respectively. It is worth noticing that the transformation temperatures are generally affected by the grain sizes; the larger the grain sizes the higher the transformation temperatures [10]. However, for this new alloy composition the grain size has been refined and the transformation temperature remains high. This fact contributes for a HTSMA with better mechanical 
properties. The interval $\left(A_{t}-A_{s}\right)$ is related to the elastic energy accumulated in the accommodation of the martensitic variants [27] and [28], therefore it can be said that the narrower its value, the easier it is for the martensites to accommodate within the austenite in this range of temperature. Thus, this interval is so called the elastic hysteresis. For the present alloy this value is around $101^{\circ} \mathrm{C}$ and can be considered as a broad hysteresis. The elastic energy stored is calculated by the expression $E_{\mathrm{el}}=\Delta S$ $\left(A_{i}-A_{s}\right)$ [27] and [28] which is $3.79 \mathrm{~J} / \mathrm{g}$. The frictional dissipated energy, which can be related to the damping properties of the material, is related with the interval $\left(A_{t}-M_{s}\right)$ that is around $71^{\circ} \mathrm{C}$. The dissipated energy is calculated from the following expression $E_{d}=\Delta S\left(A_{t}-M_{s}\right) / 2$ [27] and [28]. and is equal to $1.32 \mathrm{~J} / g$. The values of $E_{e l}$ and $E_{d}$ for similar composition without $\mathrm{Nb}$ and processed by the same route were $0.55 \mathrm{~J} / \mathrm{g}$ and $0.29 \mathrm{~J} / \mathrm{g}$ [19] respectively. Therefore, the use of $\mathrm{Nb}$ in the alloy makes the nucleation of the martensite more difficult, forcing the elastic energy and frictional energy to increase. This fact can be explained by the refined variants of martensite (around $100 \mathrm{~nm}$ ), as seen in Fig. 1(b), that makes higher the interface boundaries between the variants. It disadvantages the elastic accommodation of the variants and disturb the movement of the interfaces, making the frictional energy to increase [29]. The refined laths as well as the refined grains affect the mechanical properties, as will be further discussed. 


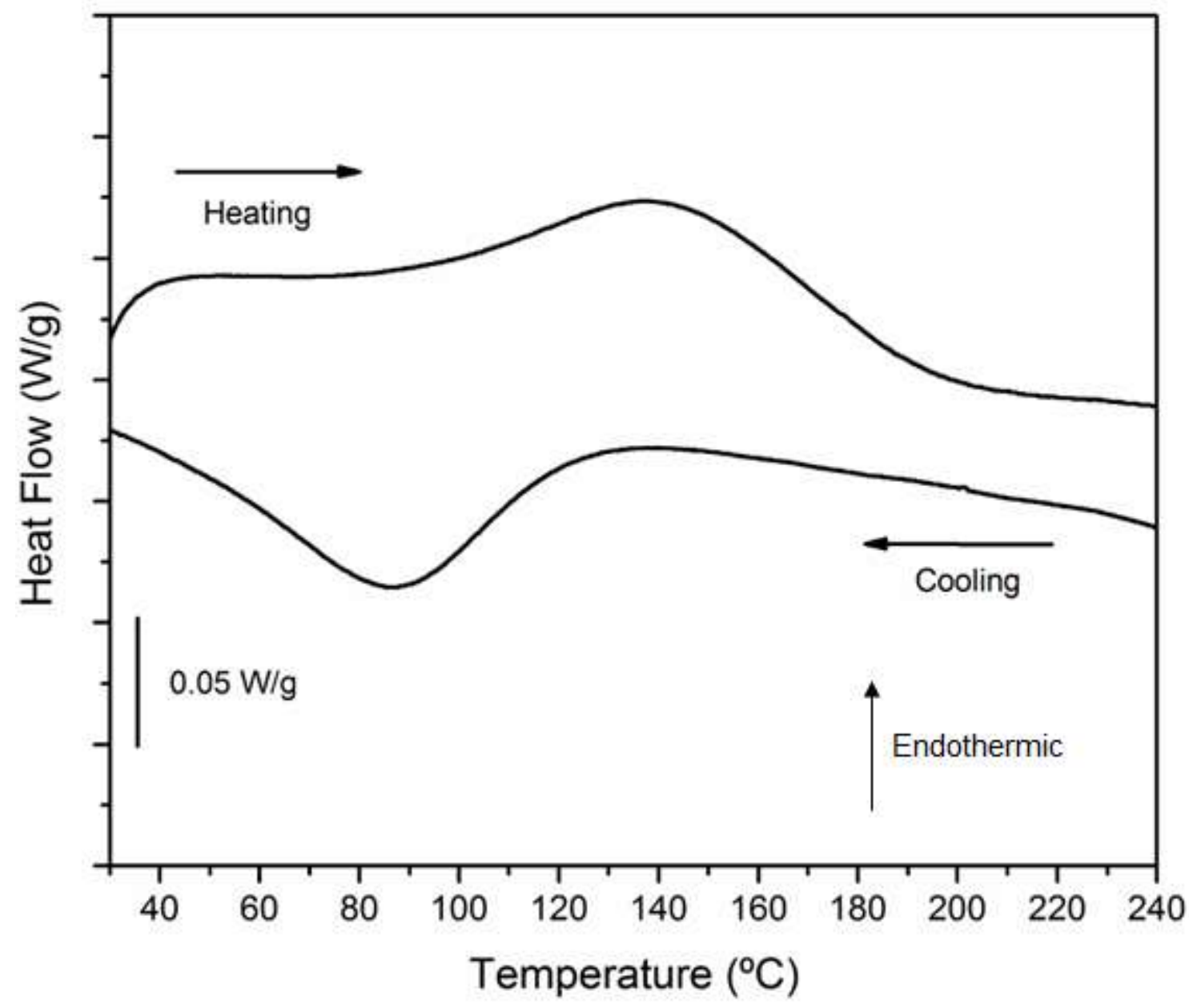

Fig. 3: DSC of the Cu-11.35Al-3.2Ni-3Mn-0.5Nb (wt\%) alloy at $40{ }^{\circ} \mathrm{C} / \mathrm{min}$ showing the forward exothermic peak and the reverse endothermic peak.

Table 1: Transformation temperatures $A_{s}, A_{f}, M_{s}, A_{f}-A_{s}, A_{f}-M_{s}\left({ }^{\circ} \mathrm{C}\right)$ and the melting point $\mathrm{T}_{\mathrm{m}}$ for the alloy $\mathrm{Cu}-11.35 \mathrm{Al}-3.2 \mathrm{Ni}-3 \mathrm{Mn}-0.5 \mathrm{Nb}$ (wt\%). The deviation is $\pm 1^{\circ} \mathrm{C}$.

\begin{tabular}{|c|c|c|c|c|c|c|}
\hline$A_{s}$ & $A_{f}$ & $A_{p}$ & $M_{s}$ & $A_{f-} A_{s}$ & $A_{f-}-M_{s}$ & $T_{m}$ \\
\hline 94 & 195 & 138 & 125 & 101 & 71 & 1003 \\
\hline
\end{tabular}

Fig. 4(a) shows the compressive stress-strain behavior of the alloy at room temperature. The compressive fracture stress and strain were $1560 \mathrm{MPa}$ and $27 \%$, respectively. The main mechanism of deformation for this alloy is the reorientation and detwinning of the martensite variants, as found in many SMA, i.e NiTi and Cu-Al$\mathrm{Ni}$ [26], [30] and [31]. As shown by XRD the predominant phase is the monoclinic $\beta^{\prime}$ martensite. Thus, the influence of other possible phases in small volume fraction is 
considered negligible in the mechanical behavior of the alloy. The refined grain and refined martensite laths in the microstructure might be the responsible for its high fracture stress. As the mechanism of deformation involves the movement of the martensites variants, the deformation will be more difficult when the size of the variants is small because of the greater number of interfaces. It will require more energy to move them and therefore higher values of stresses. For the present alloy, the value of the hysteresis $\left|A_{t}-M_{s}\right|$ reflects there is a larger frictional energy between the variants. As shown before $\left|A_{t}-M_{s}\right|=71^{\circ} \mathrm{C}$, which is considered a broad hysteresis if compared with other Cu-Al-Ni-based alloys. Fig. 4(b) compares the fracture stress and fracture strain in compression mode for other $\mathrm{Cu}-\mathrm{Al}-\mathrm{Ni}$ and $\mathrm{Cu}-\mathrm{Al}-\mathrm{Ni}-\mathrm{Mn}$ alloys with similar composition with the alloy in the present study. It can be seen that the Cu-11.35Al3.2Ni-3Mn-0.5Nb (wt\%) studied in this work presents considerably higher values than all the others alloys ( $65 \%$ higher than the best of the other alloys; alloy $\mathrm{D}$ ).

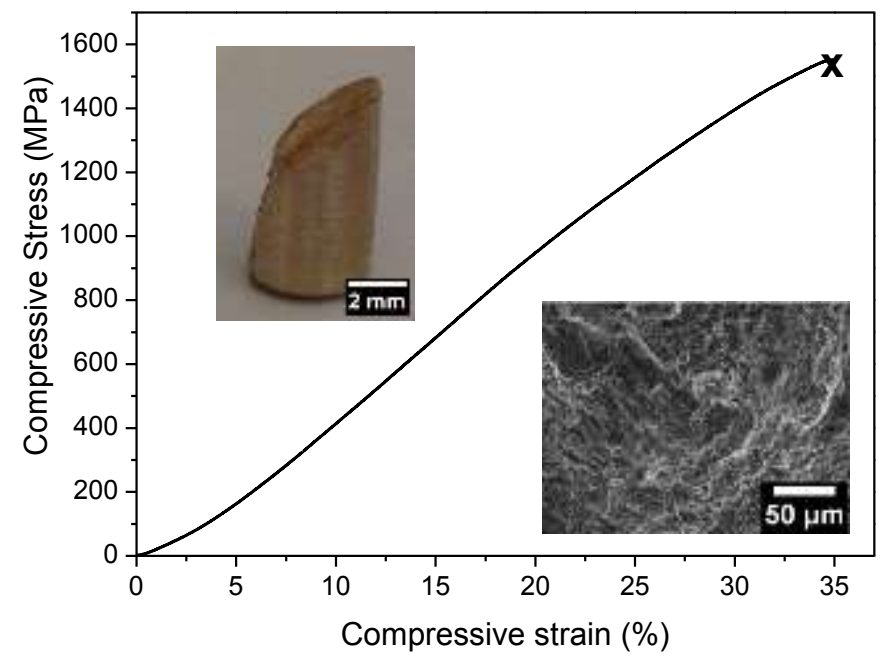

a)

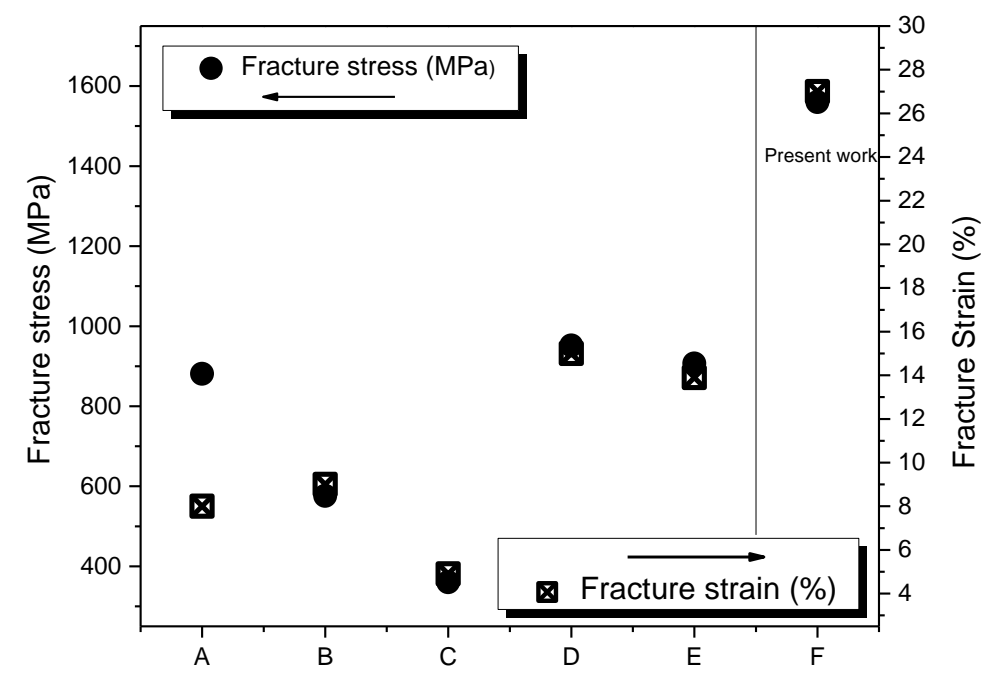

b) 

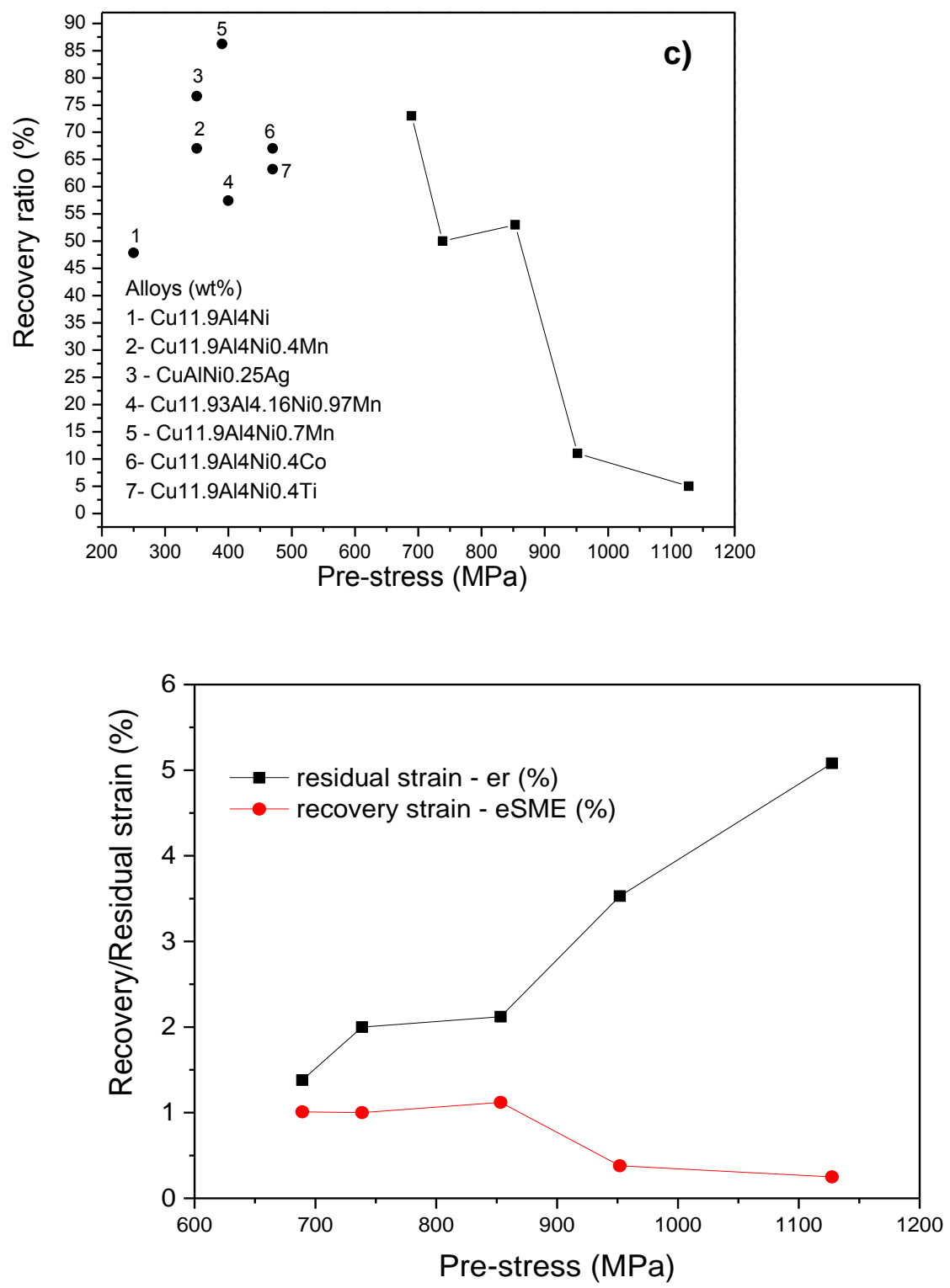

d)

Fig. 4: a) Compressive stress-strain curve for the Cu-11.35Al-3.2Ni-3Mn-0.5Nb (wt\%) alloy. The inset figures corresponds to the fractured specimen. Figure $b$ ) corresponds to values of the fracture stress and strain for other alloys in the literature, where $A=C u 11.92 \mathrm{Al} 3.78 \mathrm{Ni}$ (homogenized at $950^{\circ} \mathrm{C}$ for $120 \mathrm{~min}$ ), $\mathrm{B}=\mathrm{Cu} 11.92 \mathrm{Al} 3.78 \mathrm{Ni}$ (homogenized at $950^{\circ} \mathrm{C}$ for $40 \mathrm{~min}$ ),

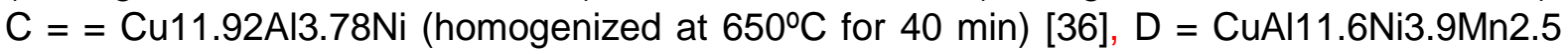
[37], $\mathrm{E}=$ Cu11.85Al3.2Ni3.0Mn [not published], all in wt\%. Figure c) shows the recovery ratio for the present alloy and alloys in the literature: 1 [36], 2 [38], 3 [39], 4 [38], 5 [38], 6 [40] and 7 Fig d) shows the recovery strain after heat treatment above $A_{f}$ and residual stress after the pre-load.

The shape recovery ratio can be seen on Fig. 4(c). It retains a value of more than $40 \%$ of recovery when the sample is subject to $900 \mathrm{MPa}$ and an outstanding shape recovery ratio of $73 \%$ when subject to $690 \mathrm{MPa}$, which has never been reported for 
Cu-Al-Ni-based high temperature alloy for this value of stress. For greater stresses, the shape recovery ratio decreases to less than $10 \%$ for stresses higher than $950 \mathrm{MPa}$. When compared to other HTSMA reported in the literature as shown in Fig. 4(c), it can be observed that the same value of the recovery ratio happens at lower stresses. In this case, it can be calculated that the recovery ratio is better for the studied alloy because of the absence or at least a less pronounced plastic deformation mechanism with the imposed pre-stresses values. The recent developed theory using the geometric compatibilities and crystalline symmetry between the austenite and martensite, the so-called geometric non-linear theory of martensite (GNLTM) [32] can explain the superior behavior of this alloy in comparison to others. This theory states that a small volume change and a crystalline compatibility between the austenite and martensite are two important factors for the thermoelasticity of the transformation [33], [34], [35] and [36]. Using the lattice parameters of the austenite and the martensite and the transformation stretches $\alpha, \beta$ and $y$ it is possible to obtain the deformation matrix for the cubic to monoclinic phase transformation using the following relationships $\alpha=a / a_{0}, \beta=b /\left(a_{0} \sqrt{2}\right), y=c /\left(a_{0} \sqrt{2}\right)$, where $a_{0}$ is the lattice parameter of the cubic unit cell and $a, b$ and $c$ are the lattice parameters of the monoclinic unit cell [34] and [35]. Eq. (1) shows the deformation matrix for one variant of the monoclinic martensite for the studied alloy. From the deformation matrix it is possible to measure the compatibility of the austenite and the martensite and the volume change in the phase transformation. The middle eigenvalue $\lambda_{2}$ is the parameter that measures the misfit between the austenite and martensite and when it is equal to 1 it means that the austenite is directly compatible with the martensite. The volume change is measured by $\operatorname{det}(\mathrm{U})$ and when it is equal to 1 means that there is no volume change due to the transformation [32], [33], [34] and [35]. Table 2 shows $\lambda_{2}$ and $\operatorname{det}(U)$ for the Cu-11.35Al-3.2Ni-3Mn-0.5Nb (wt\%) alloy and others Cu-Al-Ni-Mn of the literature with similar composition. It can be seen that for the present alloy both parameters are closer to one than the others. This explains the enhanced shape memory recovery of this alloy. Details of the calculation can be found in [35]. equation(1)

$$
U=\left(\begin{array}{ccc}
0.7713 & -0.0357 & -0.0357 \\
-000357 & 1.0957 & 0.4612 \\
-0.0357 & 0.4612 & 1.0957
\end{array}\right)
$$

Table 2: Lattice parameters and transformation stretches for the present studied alloy and CuA-Ni-Mn alloys in the literature.

${ }^{*} \alpha=a / a_{0}, \beta=b /\left(a_{0} \sqrt{2}\right), \gamma=c /\left(a_{0} \sqrt{2}\right)$, where $a_{0}$ is the lattice parameter of the cubic unit cell and $\mathrm{a}, \mathrm{b}$ and $\mathrm{c}$ are the lattice parameters of the monoclinic unit cell 
The recovery strain on Fig. 4(d) remains being $1 \%$ up to $900 \mathrm{MPa}$ and then decreases in the same interval as the shape recovery ratio, which means that some mechanism

\begin{tabular}{|c|c|c|c|c|c|c|}
\hline & $\begin{array}{l}\text { Compositio } \\
\text { n (wt\%) }\end{array}$ & $\begin{array}{l}\text { Cu11.35Al3.2N } \\
\text { i } 3 \mathrm{Mn} 0.5 \mathrm{Nb}\end{array}$ & $\begin{array}{l}\text { Cu11.9 } \\
\text { Al4Ni }\end{array}$ & $\begin{array}{l}\text { Cu11.9Al4 } \\
\text { Ni0.4Mn }\end{array}$ & $\begin{array}{l}\text { Cu11.9Al4 } \\
\text { Ni0.7Mn }\end{array}$ & $\begin{array}{l}\text { Cu11.9Al4 } \\
\text { Ni1.0Mn }\end{array}$ \\
\hline \multirow{4}{*}{$\begin{array}{l}\text { Lattice } \\
\text { parameters }(\mathrm{n} \\
\underline{\mathrm{m})}\end{array}$} & $\mathrm{a}$ & 0.4500 & 0.4425 & 0.4428 & 0.4421 & 0.4428 \\
\hline & $\mathrm{b}$ & 0.5224 & 0.525 & 0.5272 & 0.5256 & 0.5252 \\
\hline & c & 1.2825 & 3.8055 & 3.8046 & 3.7925 & 3.8043 \\
\hline & $\theta$ & $95.6^{\circ}$ & $89.9^{\circ}$ & $90.4^{\circ}$ & $90.3^{\circ}$ & $90.1^{\circ}$ \\
\hline \multirow{3}{*}{$\frac{\text { Transformatio }}{\underline{\text { n stretches }}}$} & $\alpha$ & 0.7730 & 0.7601 & 0.7606 & 0.7594 & 0.7606 \\
\hline & $\beta$ & 0.6345 & 0.6377 & 0.6404 & 0.6384 & 0.6379 \\
\hline & $\gamma$ & 1.5578 & 4.6223 & 4.6212 & 4.6065 & 4.6208 \\
\hline \multicolumn{2}{|l|}{ Eigenvalue $\lambda_{2}$} & 0.76811 & $\begin{array}{l}0.7601 \\
0\end{array}$ & 0.76060 & 0.75940 & 0.76061 \\
\hline
\end{tabular}

of plastic deformation is acting around these values of stress, hindering the reversible martensitic transformation to the original twinned orientation of the variants, which affects the shape memory effect [37]. This fact is confirmed by the residual stress increasing after $900 \mathrm{MPa}$, as seen in Fig. 4(d).

\section{Conclusion}

In summary, the phase transformation and shape memory properties of the $\mathrm{Cu}-\mathrm{Al}-\mathrm{Ni}$ $\mathrm{Mn}$ with a minor addition of $\mathrm{Nb}$ produced by spray forming have been investigated for the first time. It was found that $\mathrm{Cu}-11.35 \mathrm{Al}-3.2 \mathrm{Ni}-3 \mathrm{Mn}-0.5 \mathrm{Nb}$ (wt\%) presented shape recovery ratio of $73 \%$ when subject to $690 \mathrm{MPa}$ of compressive stress. The fracture stress for the alloy was around $1560 \mathrm{MPa}$. This new, Cu-11.35Al-3.2Ni-3Mn-0.5Nb (wt\%) alloy has proven to be a good candidate for applications at high temperature $\left(>200^{\circ} \mathrm{C}\right.$, when $\mathrm{T}>\mathrm{A}_{\mathrm{f}}$ ), where a shape memory phase transformation can be used, such as in actuation and damping devices.

\section{Acknowledgements}

The authors are grateful to M. Hartman for technical assistance and for the financial support granted by CNPq (number 202071/2014-6).

\section{References}

[1] J. Mohd Jani, M. Leary, A. Subic, M.A. Gibson Mater. Des., 56 (2014), pp. 1078-1113

[2] T. Niendorf, P. Krooß, C. Somsen, G. Eggeler, Y.I. Chumlyakov, H.J. Maier Acta Mater., 89 (2015), pp. 298-304

[3] H.E. Karaca, S.M. Saghaian, G. Ded, H. Tobe, B. Basaran, H.J. Maier, R.D. Noebe, Y.I. Chumlyakov; Acta Mater., 61 (2013), pp. 7422-7431 
[4] O. Benafan, A. Garg, R.D. Noebe, G.S. Bigelow, S.A. Padula, D.J. Gaydosh, N. Schell, J.H. Mabe, R. Vaidyanathan; Intermetallics, 50 (2014), pp. 94-107

[5] K.C. Atli, I. Karaman, R.D. Noebe; Mater. Sci. Eng.: A, 613 (2014), pp. 250-258

[6] X.L. Meng, W. Cai, L.M. Wang, Y.F. Zheng, L.C. Zhao, L.M. Zhou; Scr. Mater., 45 (2001), pp. 11771182

[7] K. Otsuka, X. Ren; Intermetallics, 7 (1999), pp. 511-528

[8] H.E. Karaca, S.M. Saghaian, B. Basaran, G.S. Bigelow, R.D. Noebe, Y.I. Chumlyakov; Scr. Mater., 65 (2011), pp. 577-580

[9] L. Kovarik, F. Yang, A. Garg, D. Diercks, M. Kaufman, R.D. Noebe, M.J. Mills; Acta Mater., 58 (2010), pp. 4660-4673

[10] K. Otsuka, C.M. Wayman; Shape Memory Materials; Cambridge University Press, Cambridge, United Kingdom (1998)

[11] J. Lelatko, H. Morawiec; Mater. Chem. Phys., 81 (2003), pp. 472-475

[12] J. Lelatko, H. Morawiec; Le J. Phys. IV, 11 (2001) Pr8-487-Pr488-492

[13] J. Lelatko, H. Morawiec; Mater. Sci. Eng.: A, 481-482 (2008), pp. 684-687

[14] C. Liu, H.W. Mu; J. Alloy. Compd., 508 (2010), pp. 329-332

[15] C.P. Wang, Y. Su, S.Y. Yang, Z. Shi, X.J. Liu; Smart Mater. Struct., 23 (2014), p. 025018

[16] S. Yang, Y. Su, C. Wang, X. Liu; Mater. Sci. Eng.: B, 185 (2014), pp. 67-73

[17] R. Dasgupta; J. Mater. Res., 29 (2014), pp. 1681-1698

[18] E.M. Mazzer, C.S. Kiminami, P. Gargarella, R.D. Cava, L.A. Basilio, C. Bolfarini, W.J. Botta, J. Eckert, T. Gustmann, S. Pauly; Mater. Sci. Forum, 802 (2014), pp. 343-348

[19] R.D. Cava, C. Bolfarini, C.S. Kiminami, E.M. Mazzer, W.J. Botta Filho, P. Gargarella, J. Eckert; J. Alloy. Compd. (2013)

[20] D.W. Roh, J.W. Kim, T.J. Cho, Y.G. Kim; Mater. Sci. Eng.: A, 136 (1991), pp. 17-23

[21] M.A. Morris; Acta Metall. Mater., 40 (1992), pp. 1573-1586

[22] J. Dutkiewicz, T. Czeppe, J. Morgiel; Mater. Sci. Eng.: A, A273 (1999), pp. 703-707

[23] Z. Xiao, Z. Li, M. Fang, S. Xiong, X. Sheng, M. Zhou; Mater. Sci. Eng.: A, 488 (2008), pp. 266-272 [24] J. Ma, I. Karaman, R.D. Noebe; Int. Mater. Rev., 55 (2010), pp. 257-315

[25] Y. Sutou, T. Omori, R. Kainuma, K. Ishida; Acta Mater., 61 (2013), pp. 3842-3850

[26] S.K. Vajpai, R.K. Dube, S. Sangal; Mater. Sci. Eng.: A, 570 (2013), pp. 32-42

[27] H. Kato, Y. Yasuda, K. Sasaki; Acta Mater., 59 (2011), pp. 3955-3964

[28] E.M. Mazzer, C.S. Kiminami, C. Bolfarini, R.D. Cava, W.J. Botta, P. Gargarella; Thermochim. Acta, 608 (2015), pp. 1-6

[29] J. Rodríguez-Aseguinolaza, I. Ruiz-Larrea, M.L. Nó, A. López-Echarri, E.H. Bocanegra, J. San Juan; Intermetallics, 18 (2010), pp. 2183-2190

[30] Y. Liu, Y. Li, K.T. Ramesh, J.V. Humbeeck; Scr. Mater., 41 (1999), pp. 89-95

[31] R. Zarnetta, R. Takahashi, M.L. Young, A. Savan, Y. Furuya, S. Thienhaus, B. Maaß, M. Rahim, J. Frenzel, H. Brunken, Y.S. Chu, V. Srivastava, R.D. James, I. Takeuchi, G. Eggeler, A. Ludwig; Adv. Funct. Mater., 20 (2010), pp. 1917-1923 
[32] J. Cui, Y.S. Chu, O.O. Famodu, Y. Furuya, J. Hattrick-Simpers, R.D. James, A. Ludwig, S. Thienhaus, M. Wuttig, Z. Zhang, I. Takeuchi; Nat. Mater., 5 (2006), pp. 286-290

[33] K.F. Hane, T.W. Shield; Acta Mater., 47 (1999), pp. 2603-2617

[34] R.D. James, K.F. Hane; Acta Mater., 48 (2000), pp. 197-222

[35] C.E. Sobrero, P. La Roca, A. Roatta, R.E. Bolmaro, J. Malarría; Mater. Sci. Eng.: A, 536 (2012), pp. 207-215

[36] U. Sarı, T. Kırındı; Mater. Charact., 59 (2008), pp. 920-929

[37] U. Sari; Int. J. Miner. Metall. Mater., 17 (2010), pp. 192-198

[38] S.N. Saud, E. Hamzah, T. Abubakar, H.R. Bakhsheshi-Rad, M. Zamri, M. Tanemura; J. Mater.

Eng. Perform., 23 (2014), pp. 3620-3629

[39] S.N. Saud, E. Hamzah, T. Abubakar, H.R. Bakhsheshi-Rad, S. Farahany, A. Abdolahi, M.M. Taheri; J. Alloy. Compd., 612 (2014), pp. 471-478

[40] S.N. Saud, T.A. Abu Bakar, E. Hamzah, M.K. Ibrahim, A. Bahador; Metall. Mater. Trans. A, 46 (2015), pp. 3528-3542

[41] S.N. Saud, E. Hamzah, T. Abubakar, M. Zamri, M. Tanemura; J. Therm. Anal. Calorim., 118 (2014), pp. 111-122 